A Journal of Agricultural Science Publisbed by the California Agricultural Experiment Station

HOST ORGANS ATTACKED BY BACTERIAL CANKER OF STONE FRUITS

EDWARD E. WILSON and WM. B. HEWITT

FACTORS AFFECTING DEVELOPMENT OF THE BACTERIAL CANKER OF STONE FRUITS EDWARD E. WILSON

SOME FACTORS AFFECTING THE SUSCEPTIBILITY OF PLANTS TO FIRE BLIGHT

H. EARL THOMAS and P. A. ARK 


\section{SOME FACTORS AFFECTING THE SUSCEPTIBILITY OF PLANTS TO FIRE BLIGHT}

H. EARL THOMAS AND P. A. ARK 



\title{
SOME FACTORS AFFECTING THE SUSCEPTIBILITY OF PLANTS TO FIRE BLIGHT ${ }^{1,2}$
}

\author{
H. EARL THOMAS ${ }^{3}$ AND P. A. ARK ${ }^{4}$
}

STUDENTS OF FIRE BLIGHT (caused by Bacillus amylovorus) for a century or more $(4)^{5}$ have made observations which suggested that the environment of the inherently susceptible plant has a marked influence on the degree of susceptibility in any given situation. Certain elements of the environment have been studied exhaustively in more recent times, while others are still somewhat neglected.

In the work reported in this paper, consideration has been given to some of the factors which might be expected to affect the degree of susceptibility of a given plant, and more particularly those which might give some clue as to the nature of resistance to this disease. A few of the points dealt with have to do rather with escape than true resistance.

\section{MORPHOLOGY OF THE PLANT IN RELATION TO INFECTION}

Apart from wounds made by insects and other agencies, the entrance of the blight organism into the plant seems to be limited largely or entirely to natural openings, particularly in the nectaries and to a less extent in certain other flower parts (31), the stomata of the leaves $(14,30)$, and probably also on the very young fruits $(26)$ and shoots. It now seems probable $(8,17,36)$ that penetration from the nectary into the receptacle, at least in the pear and apple, is through openings similar to or identical with the stomata.

There is a persistent impression, however, among pear growers and others, that infections may develop in the older bark of trunks, crotches, or large branches in the absence of any discernible shoot, spur, or wound. With this in mind, in three experiments, pear branches of varying ages up to about seven years were cut into convenient lengths and kept in a highly humid atmosphere until the whitish parenchyma tissues began to be exserted at various places on the surface. The blight organism was then applied to these tissues with a camel's-hair brush. No infection fol-

\footnotetext{
${ }^{1}$ Received for publication July 26, 1938.

${ }^{2}$ Assistance was received in parts of this work from L. Daniels, N. M. Heisinger, and B. Steele, students in the University and employees of the National Youth Administration, and from the federal Work Progress Administration.

${ }^{3}$ Associate Plant Pathologist in the Experiment Station.

' Junior Plant Pathologist in the Experiment Station.

"Italic numbers in parentheses refer to "Literature Cited" at the end of this paper.
} 
lowed. Under these conditions, however, the killing produced by inoculation through needle punctures was slight (up to $2 \mathrm{~mm}$ from the point of inoculation in 10 days). Nevertheless, if the long experience of many workers in the orchard is included as evidence, it seems probable that the organism seldom if ever penetrates the bark directly in the absence of wounds.

Nixon (29) has pointed out that the path of migration of the bacteria within the plant usually lies in the outer cortical tissues which have large intercellular spaces, and some workers infer that the size of the spaces

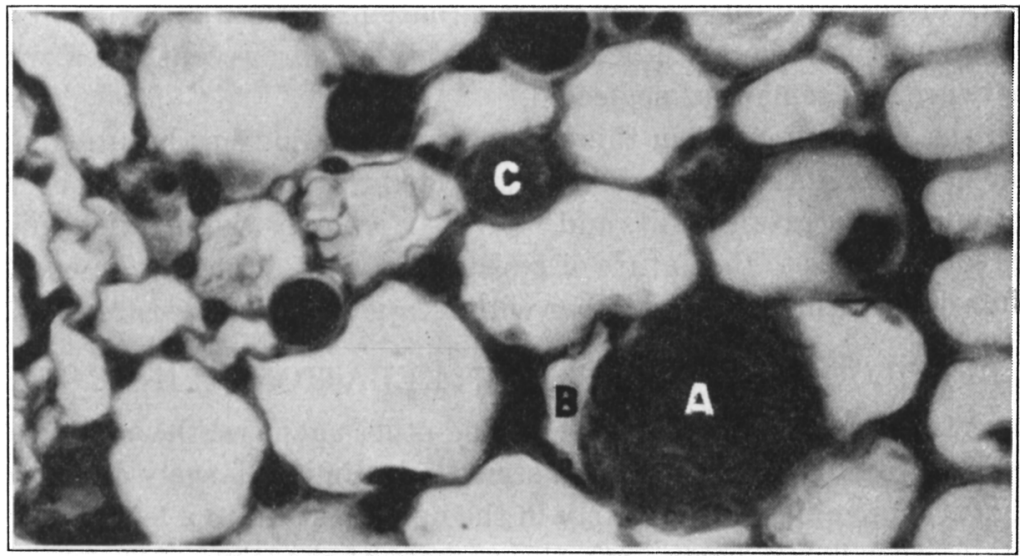

Fig. 1.-Parenchyma in midvein of leaf of Pyracantha angustifolia showing bacterial masses of various sizes in the intercellular spaces as at $A$ and $C$. The cell walls are giving way, apparently under pressure from the masses, and at $B$ a cell is almost entirely collapsed but apparently not yet invaded.

is a factor in determining the region to be invaded. The fact of selection of these tissues is unmistakable : in the older pear branches, the organism may advance for at least 12 inches and cease activity without killing the inner bark. To study this point further, transverse sections were cut from stems of the susceptible Cotoneaster pannosa about $1 / 2$ inch from the growing tip and again about 2 inches from the tip. The latter would represent distinctly less-susceptible tissues. However, the intercellular spaces here were much larger than in the younger tissues. Sections were also prepared from comparable younger tissues ( $1 / 2$ inch from the tip) of the virtually immune $C$. Franchetii. In these, 20 of the larger spaces in the parenchyma chosen more or less at random (by an assistant) averaged 35 by 82 microns, whereas 20 corresponding spaces in the younger tissues of $C$. pannosa averaged 27 by 53 microns. While it seems to be true in general that the larger spaces are in the tissues traversed by the migrat- 
ing masses of bacteria (zoogleae) (29), the facts just given indicate that the size of intercellular spaces is not a primary controlling factor in the movement of the organism in the plant. This view is further supported by a study in sections of tissues recently invaded by the organism (fig. 1). These show, as Bachmann (3) has pointed out, that the spaces are readily enlarged in response to the pressure or some other influence of the zoogleae. Thus the bacteria may come to occupy almost the entire space formerly occupied by a cell without having invaded the cell. Furthermore, in cross sections of invaded stems the spaces actually occupied by the bacterial masses are often much smaller than others nearby which are not occupied (29).

The interesting alignment of the bacterial cells parallel with the line of advance reported by Nixon (29) and Haber (12) has been observed in our sections, but only in intercellular spaces which are relatively long and narrow. Probably this alignment is an instance of the general physical phenomenon of orientation due to laminar flow observable when rod-shaped particles suspended in a fluid are passed through a tube of small diameter (10). This point is of interest as an additional indication that the organism is nonmotile in this phase (29) and merely carried by the moving matrix.

\section{HUMIDITY IN RELATION TO INFECTION}

Although earlier work (7) indicated that the optimum atmospheric humidity for infection was about 80 per cent, the more recent and exhaustive work of Shaw (38) has shown beyond reasonable doubt that an atmosphere near saturation is most favorable. This fact is perhaps responsible in some measure for the seemingly excessive emphasis which has been placed upon water as an agent of dissemination (26).

The results with the different methods of inoculation are no doubt related to humidity or desiccation (see also section on age of wounds, p. 310). On several occasions, apple and pear trees in both New York and California were inoculated in wounds of various kinds. These experiments may be sufficiently represented by one made on Bartlett pear near Walnut Grove, California, on May 21, 1930. The weather during this period was relatively dry. Twenty-five current-season shoots and 25 branches two to three years old were cut off with pruning shears, each cut being preceded by a cut through an active canker. In a third lot, 25 wounds were made by cutting off the outer bark with a sharp knife; the exposed surfaces were then smeared with a water suspension of the bacterial exudate. Finally, 25 ragged wounds were made by gouging into the bark with the point of a knife and inoculated as in the preceding 
lot. In these four lots, respectively $2,2,0$, and 1 , infections resulted. Of 10 shoots inoculated near the tips at the same time by puncturing with a needle dipped in the bacterial suspension, 9 became blighted.

Studies of nectars (6) and of cultures containing varying concentrations of the sugars found in nectars (41) have shown that the concentration of sugars in the nectar is inversely related to atmospheric humidity and very probably limiting to the penetration of the blight organism into the plant at low atmospheric humidities.

Hildebrand has recently concluded (15) that Thomas and Ark (41) "probably have exaggerated the importance of nectar dilution by rain in bringing about blossom infection, because other openings than those found in the nectary, and particularly the stigmas, were left out of consideration by them as infection courts," and that "only in the pear, which has an open receptacle, would the desiceating influence of the atmosphere be strongly inhibitive." Several pertinent facts seem to have been overlooked in arriving at these conclusions. First, the fluctuations in atmospheric humidity rather than direct dilution of the nectar by rain is the factor believed to influence greatly the inception of infection; second, the concentration of the nectar in the plants with sheltered nectaries has been shown to be readily altered by changes in atmospheric humidity, although somewhat less rapidly than is the case with plants having more exposed nectaries $(5)^{6}$; and third, Pierstorff (31), working in New York in association with one of the present writers, studied in some detail the infection of stigmas and other flower parts of pear and apple blossoms as early as 1925 and 1926 and reached the conclusion, probably still valid with respect to petals and stigmas, that "under field conditions the number of infections resulting from the entrance of bacteria through these infection courts is small."

After penetration has taken place, the concentration of the sap as well as humidity per se (38) may possibly be an important controlling factor, although since these are no doubt to a considerable degree in inverse relation, the complete separation of these factors does not seem possible at present. The osmotic pressure of sap of apple leaves has been shown (21) to vary from between 7 and 9 atmospheres at a time of heavy rainfall and low temperature to between 20 and 23 in relatively dry periods. A similar change in Bartlett pear leaves at Berkeley from 11.7 atmospheres on April 2 to 24.2 on August 4 has been noted by J. P. Bennett (unpublished). Much wider fluctuations in osmotic values have been

\footnotetext{
${ }^{6}$ In one of our own tests, apple blossoms on branches kept overnight in an atmosphere near saturation yielded nectar with a sugar content of 6 to 7 per cent, while blossoms similarly treated except exposed to the laboratory air contained 35 to 44 per cent sugar.
} 
reported for the desert plant Larrea tridentata (25), only part of which are apparently referable to changes in moisture supply, Apparently these agencies are less sharply limiting after infections are well established, as evidenced among other things by the "water-soaked" condition of the tissues at the margins of active cankers and the plasmolysis of cells (3) in early stages of infection. The production of a toxin capable of wilting susceptible shoots has been demonstrated (31) for the blight organism. Interference with the water retention in plant cells by materials toxic to the tissues seems to be a rather general phenomenon (18).

The relation of soil water to blight infection has not been extensively studied. In experiments in the greenhouse with potted plants (42), maintaining the water content of the soil near the wilting point caused a striking reduction in the extent of infections. Apple and pear trees grown in soil with controlled water content at 40 to 50 per cent of capacity and apparently never allowed to reach the wilting point have been shown $(37,38)$ to possess greater resistance than trees grown at 80 to 90 per cent. In a field experiment at San Jose, several hundred three-yearold seedling pear trees were inoculated in the trunks 4 to 6 inches below the ground line. The soil was replaced and part of these were irrigated within the next 24 hours so that the soil around the points of inoculation was wet. This was done in the middle of the dry season, July 16 , and the number infected was low in both lots, 8 of 100 in the irrigated rows and 6 of 50 in the rows not irrigated at that time.

In small-scale tests, the application of slightly increased water pressure to the roots of Cotoneaster Franchetii and to the stems of Pyracantha angustifolia produced no perceptible change in the resistance of the former or the degree of susceptibility of the latter, which blighted to 2.3 inches from the tips in 4 treated plants and 2.4 inches in 4 control plants. The pressure on the latter species was obtained by a column of water 8 feet above soil level and on the former by a somewhat shorter column. Two large potted plants of $P$. angustifolia were subjected to controlled water pressure of 20 and 28 pounds beginning at the time of inoculation and continuing for 4 and 5 days respectively, without perceptible increase in susceptibility. A plant of Cotoneaster glaucophylla similarly exposed to a pressure of 20 pounds remained immune. There was no visible "water-soaking" in any of these treated plants. Considerably higher water pressures have been shown (20) to increase enormously the susceptibility of tobacco and other plants to bacterial pathogenes. In view of the relatively high internal pressures which plants seem capable of developing (44), perhaps the addition of a few pounds should not be expected to produce any marked change. 


\section{RELATION OF TEMPERATURE TO INFECTION}

Some indirect effects of temperature on fire blight have already been pointed out (42). Evidence from many sources indicates that blight infection may be active over a wide range of temperatures but is favored by relatively high temperatures. This is well illustrated by the destructiveness of the disease in the more humid areas of the southern United States. On the basis of controlled experiments, the optimum temperature has been placed between $70^{\circ}$ and $80^{\circ} \mathrm{F}(7)$. The optimum temperature for the bacteria in culture seems to be about $83^{\circ} \mathrm{F}(2)$. There is probably no upper limit of temperature under natural conditions. The bacteria in blighting shoots $1 / 16$ to $1 / 4$ inch in diameter are able to withstand external air temperatures of 4 hours at $118^{\circ} \mathrm{F}$, or 30 minutes at $140^{\circ} \mathrm{F}(42)$. On the other hand, low temperatures are known to retard or arrest the development of infections. In areas with mild winters, direct evidence can be seen of temperature as a limiting factor in the enlargement of cankers. Those cankers which have entirely girdled the branches are often found to advance several inches more during the winter months on the side exposed to the sun than on the opposite side. A relation of low temperatures to initiation of infection is also indicated by results of an experiment in which alternate rows of seedling pear trees, $1 / 2$ to $11 / 4$ inches in trunk diameter, were inoculated on the north and south sides of the trunks at San Jose, February 19, 1936. On April 7, 15 per cent of 73 trees inoculated on the north side and 28.5 per cent of 56 trees inoculated on the south side were infected.

\section{RELATION OF LIGHT TO INFECTION}

The effect of heavy shading or complete darkness on infection has been briefly reported (42) and, since it was slight, will not be treated in detail. The etiolated shoot tips of shaded plants blighted somewhat more rapidly, but the stems developed on these plants before the experiment began were less affected. Thus, in one experiment with pear seedlings, the organism penetrated to or into the preceding growth cycle in 12 of 20 shaded plants and 17 of 20 controls in 11 days.

\section{NUTRITION AND GROWTH STAGE IN RELATION TO INFECTION}

The close relation between susceptibility and the vigor of the tree has long been a matter of common knowledge. Even though several workers $(7,16,28,37,39)$ in more recent time have presented experimental proof, this factor is not always given adequate consideration. 
The relation of nitrogen supply to infection is readily seen in tests with root-bound plants of Pyracantha angustifolia. In one of several such experiments, 20 plants in 6 -inch pots of poor soil were selected in pairs, and one of each pair received $1 / 4$ gram of calcium nitrate. All were inoculated at the tip 5 days later, and the length of the blighted part measured 13 days after inoculation. The average for those with added nitrogen was 5.9 inches (5.0 to 7.2) and for the untreated 2.2 inches (1.5 to 3.2 ). In this experiment, all the plants became infected; but in others, the number of infections, as well as the rate of extension, was increased by addition of nitrogen. Thus plants of the same species were given calcium nitrate in 3 of 6 flats, each treated flat receiving 2 applications of 5 grams with an interval of 5 weeks between. All were inoculated 5 weeks after the last applications. Eleven days later, 62.5 per cent of 176 plants with added nitrogen were blighted, as compared with 40.0 per cent of 190 plants in the untreated flats.

That the young, actively growing parts of a plant are in general much more susceptible than older parts even only a few inches distant, is so well known as to hardly require mention (42). A few exceptions, however, seem to have been noted (34). Observations in orchards and on several thousand seedling trees inoculated in the trunks at different times indicate that the bark of the trunks and main branches of pear trees is more susceptible at the end of the growing season than in midseason or earlier; but this may be due to the higher relative humidities usually prevalent in autumn.

As distinct from the nutrition of the suscept may be mentioned that of the pathogene in artificial cultures, which has recently been shown (2) to increase or decrease the virulence of the organism according, among other things, to the concentration of sugars in the medium.

It has also been suggested that arbutin (31) and asparagin (2), which are utilized by the organism in cultures and believed to be present in the actively growing parts of the pear or apple $(24,28,43)$, may bear some relation to susceptibility. With arbutin in mind, inoculations were made (at Ithaca, New York) on shoots, fruits, and leaves of the following, at least some of which are considered to be rich in arbutin : Arctostaphylos Uva-ursi, Epigaea repens, Gaultheria procumbens, Vaccinium vacillans. No infection followed.

In the case of asparagin, Ark (2) has already reported that additions of this compound to the inoculum or injection into the plant seemed to accelerate infection in comparatively resistant tissues. More recently, inoculations have been made on 12 species of rosaceous plants with and without asparagin added to the inoculum (a water suspension or, in one 
case, beef-peptone broth). There was a small but consistent increase in the extent of disease in plants which are susceptible under ordinary conditions. For example, 20 paired shoots of Pyracantha angustifolia were inoculated, half of them with asparagin added to the inoculum. The latter averaged 2.22 inches in length of blighted shoot after 14 days while the controls averaged 1.65 inches. The presence of asparagin did not induce susceptibility in plants which are ordinarily immune or nearly so, such as Cotoneaster Franchetii, C. glaucophylla, C. Harroviana, C. lactea, and Rosa Soulieana.

\section{WOUNDS AND WOUND REACTIONS IN RELATION TO INFECTION}

Wounds are of interest, not only as portals of entry of the organism into the plant, but for the further reason that the margins of infected areas seem to be in certain ways comparable to those of wounds caused by other agencies. Moreover, wounds which interfere with the movement of nutrients may alter the susceptibility of adjacent tissues.

Girdling.--In mid-June 1930, 184 Yellow Newtown apple trees were girdled on the upper trunks by the Department of Pomology of Cornell University at Ithaca, New York. This was done by cutting through the bark to the wood without removing any of the bark. Of these trees, 64 developed blight starting at the ring ; 81 per cent of the cankers extended farther above than below the ring, and 65 per cent were limited to the bark above the ring. Only 7 per cent of the cankers were entirely below the ring. A similar observation from the same orchard has recently been reported (16).

In the case just cited, inoculation may have been effected at the time of girdling or, as seemed more likely, within the next few days (by insects). An experiment was therefore devised to test the effect of girdling when the inoculum was applied at the time of wounding. For this purpose, several score of seedling pear trees were partially girdled at San Jose in June, 1935, by cutting through the bark around one-fifth to onethird of the circumference of the trunk. A roll of cheesecloth was clamped to the back and sides of the knife used in making the cuts and this was kept moist with the inoculum. Thirty-seven infections were found 6 weeks later; 73 per cent of these extended farther above than below the ring while 24 per cent were larger below the ring. The average length of the cankers was 3.27 inches above the ring and 1.75 inches below.

Several experiments in some respects related to the girdling of stems were made on potted plants of Pyracantha and Cotoneaster in the greenhouse. In these, 2 to 4 inches below the points of inoculation (tips of 
shoots), wounds were made by puncturing the stem once or twice with a fine needle, by constriction with rubber bands, or by abrading the surface with powdered carborundum. It was assumed that these treatments would not greatly interfere with translocation but might cause the neighboring tissues to develop some substance unfavorable to the passage of the blight organism. The effects of such wounds were slight. The length of blighted part was somewhat greater on wounded shoots than on comparable control shoots in three of four experiments but not significantly so in any one of them. In a total of 72 wounded shoots of which 64 became infected in seven tests, the infection stopped at the points of wounding in 13 but advanced beyond these points in 29 others.

TABLE 1

Relation of Defoliation to Infection in Shoots of Pyracantha Angustifolia

\begin{tabular}{|c|c|c|c|c|}
\hline Experiment & $\begin{array}{l}\text { Interval from } \\
\text { defoliation to } \\
\text { inoculation }\end{array}$ & Treatment & $\begin{array}{c}\text { Number } \\
\text { of } \\
\text { plants }\end{array}$ & $\begin{array}{l}\text { Average length } \\
\text { of blighted } \\
\text { part }\end{array}$ \\
\hline $1 \ldots \ldots \ldots \ldots$ & $\begin{array}{c}\text { days } \\
7\end{array}$ & $\left\{\begin{array}{l}\text { Defoliated } \\
\text { Controls }\end{array}\right.$ & $\begin{array}{l}8 \\
8\end{array}$ & $\begin{array}{c}\text { inches } \\
5.09 \\
8.56\end{array}$ \\
\hline 2. & 6 & $\left\{\begin{array}{l}\text { Defoliated } \\
\text { Controls }\end{array}\right.$ & $\begin{array}{l}6 \\
6\end{array}$ & $\begin{array}{l}0.45 \\
3.95\end{array}$ \\
\hline $3 \ldots$ & 3 & $\left\{\begin{array}{l}\text { Defoliated } \\
\text { Controls }\end{array}\right.$ & $\begin{array}{l}10 \\
10\end{array}$ & $\begin{array}{l}2.30 \\
3.75\end{array}$ \\
\hline
\end{tabular}

Removal of Growing Points.-To determine whether the growing tips of shoots have any important influence on infection, a single experiment was made in which 10 plants of Pyracantha angustifolia were inoculated about $11 / 4$ inches below the tips, and the tips of 5 were cut off at the same time. All became infected, and after 10 days the average length of blighted shoot was 3.2 for the treated and 3.4 inches for the control plants.

Defoliation.-In blight-control work the infections which are overlooked, especially near the distal ends of heavily pruned branches, often seem to be retarded for some time afterward. The case (1) may be cited here of an orchard in Lake County in which the trees were severely affected by blight in the spring of 1934. A number of these trees were almost completely defoliated in April, 1934, by heading back many of the main branches and cutting off most of the spurs and small branches. Several competent observers agreed that the development of infections on these trees was stopped distinctly earlier than on similarly infected trees in the same orchard on which the cutting was much less drastic. 
These and other observations prompted several experiments (in the greenhouse) designed to test more specifically the relation of defoliation to infection. In the first of those represented in table 1, all of the leaves were removed from the treated plants. This resulted in so obvious a decline in the plants that in the two later experiments the leaves were removed from the upper half of the stem only. All the plants became infected except 3 defoliated in experiment 2 . The plants of this test were root-bound and in rather low vigor, which no doubt accounts in some measure for the greater difference between treated and control plants in this experiment.

TABLE 2

RELAtion of AgE of Wounds AND HUMidity* to INFECTion in Shoots of Pyracantha ANGustifolia

\begin{tabular}{|c|c|c|c|}
\hline Experiment & $\begin{array}{c}\text { Age of } \\
\text { wounds }\end{array}$ & $\begin{array}{l}\text { Number of } \\
\text { shoots }\end{array}$ & $\begin{array}{l}\text { Number of } \\
\text { infections }\end{array}$ \\
\hline $1 \ldots \ldots \ldots \ldots \ldots$ & $\begin{array}{l}\text { hours } \\
\left\{\begin{array}{c}27 \\
0\end{array}\right.\end{array}$ & $\begin{array}{l}5 \\
5\end{array}$ & $\begin{array}{l}0 \\
5\end{array}$ \\
\hline $2 \ldots$ & $\left\{\begin{array}{l}6 \\
0\end{array}\right.$ & $\begin{array}{l}15 \\
15\end{array}$ & $\begin{array}{r}3 \\
13\end{array}$ \\
\hline $3 \ldots \ldots \ldots \ldots \ldots \ldots \ldots \ldots \ldots$ & $\left\{\begin{array}{l}6 \\
0\end{array}\right.$ & $\begin{array}{l}15 \\
15\end{array}$ & $\begin{array}{r}8 \\
10\end{array}$ \\
\hline $4 \ldots$ & $\left\{\begin{array}{l}6 \\
0\end{array}\right.$ & $\begin{array}{l}15 \\
15\end{array}$ & $\begin{array}{l}8 \\
8\end{array}$ \\
\hline
\end{tabular}

* See text, below.

Wounds of Different Ages as Infection Courts.-Previous work (7, 42) has shown that wounds in leaves and stems of the apple and the roots of pear trees become closed to invasion by the blight organism within 72 hours. Some additional experiments with shoots of Pyracantha angustifolia are summarized in table 2 . The shoots were wounded by single needle punctures near the tips, and the bacteria were applied to the wounds in water suspension with a camel's-hair brush immediately after the last wounds were made in each experiment. The plants of the first and second experiments were kept in the greenhouse throughout; those of the third were kept in a moist chamber for 4 days beginning just after inoculation, so that the first set of wounds were exposed to dry air for 6 hours before inoculation; and those of the fourth for 5 days beginning when the first plants of this experiment were wounded. The results indicate that wounds became unfavorable to infection more quickly than has been supposed and that humidity is important but perhaps not the only cause of the differences shown in the table. 
Direct tests were made on sections of bark adjacent to wounds of different ages for the presence of gums, pentosans, suberin, and other substances, chiefly by the methods outlined by Rawlins (33). The reagents used most extensively were orcinol, phloroglucinol, and Sudan IV. The wounds were made by cutting longitudinal slits in the bark of growing

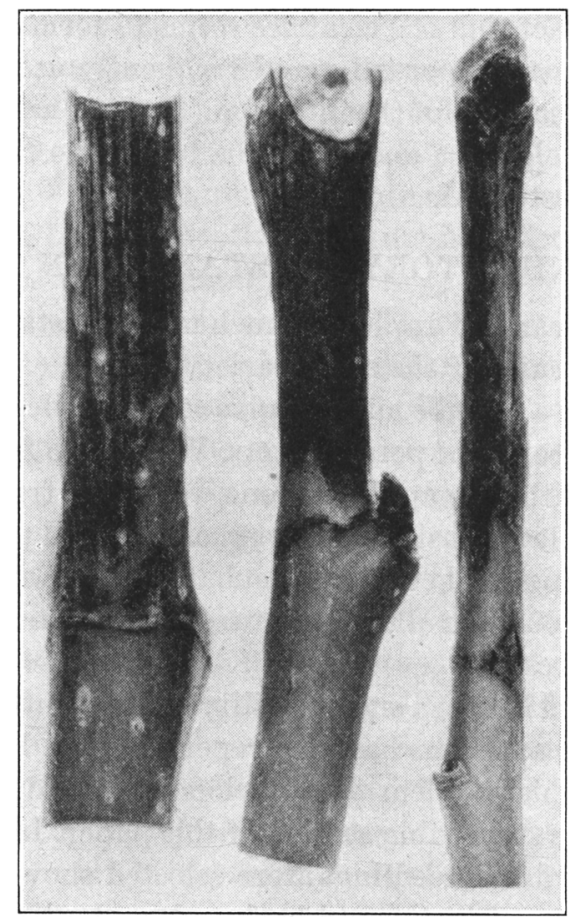

Fig.2.-The formation of a cicatrice in blighted pear bark beyond the margin of the dead bark.

shoots. At least 16 species of plants in the genera Cotoneaster, Eriobotrya, Photinia, Pyracantha, and Pyrus were used. These provided a range from highly susceptible to completely immune individuals.

There was no evidence of a relation between susceptibility and any of the staining reactions which were tested. For example, the apple (Pyrus malus) and pear (Pyrus Kawakamii), which are susceptible, gave a suberin reaction on the third day from the time of wounding and so did Cotoneaster Franchetii and $C$. Harroviana which are virtually immune. The susceptible loquat (Eriobotrya japonica) gave no positive reaction within 5 days with any of the three reagents mentioned above. 
Occasionally among seedlings of the Surprise pear there appear individuals with thick, corky bark on parts only two or three years old. One such tree was propagated and later inoculated in the greenhouse. This did not seem to be more resistant than the average pear seedling.

That some factor other than the suberin which eventually appears in the cicatrice, probably operates to arrest the advance of the infection, is suggested by the fact that the cicatrice seems to form after the advance has stopped, at least temporarily, and frequently at some distance beyond the apparent margin of the infection (fig. 2). Shaw (37) has shown, however, that the cicatrice does oppose a barrier to the renewal of advance from an arrested infection.

\section{POSSIBLE INHIBITORY SUBSTANCES IN THE PLANT}

Mature fruits of pear and apple are much more resistant to blight infection than young fruits of the same variety. Elmer (9) has shown that ripe apple fruits in a closed container give off a volatile substance capable of inhibiting the growth of potato shoots. With these facts in mind, four tests were made with ripe apple and one with pear fruit in which slices of the fruit were placed inside the covers of inverted petri-dish cultures of the blight organism. These were incubated at $25^{\circ}$ and $28^{\circ} \mathrm{C}$. The organism grew vigorously in all such cultures and apparently fully as well as in control cultures.

A partial parallel between susceptibility and the anthocyanin pigment in the bark of pear seedlings has been reported (40). Further tests were made bearing on this problem with the lots of hybrid Pyracantha seedlings treated in the succeeding section of this paper. In two of these lots, 20 , and in the third, 25, seedlings were selected showing the most pronounced red pigment which could be found, and a like number in each lot showing the least red pigment. The numbers of infections in the first lot were 6 red and 11 green, but the corresponding figures for the other two lots were 14 red to 12 green and 14 red to 8 green. There was no marked difference in average extent of the infections between the two groups in any of these tests. The last two tests were made in a heated greenhouse near midwinter. The red-stemmed plants were not strongly pigmented under these conditions and seemed to be somewhat more vigorous than the green plants.

In a further test with pear, shoots from the stocks of older orchard trees were selected in contrasting groups according to the amount of red pigment in the bark at the time of collection. These were bench-grafted on seedling roots, grown in the field for two seasons, and inoculated at the tips of shoots in the spring of the third season. The contrast in color 
did not persist under these conditions and the 39 surviving plants selected as "red" blighted quite as readily ( 69 per cent) as the corresponding 35 "green" plants ( 60 per cent) blighted. Probably the red pigment is related to blight resistance only in so far as it is associated with unfavorable growth conditions of the plants or in some other indirect way.

The toxicity of phenolic substances to bacteria in general is well known, and several of them have been tested against the fire-blight organism. The following are toxic to the organism in the concentrations indicated : hexylresorcinol $1: 10^{3}$, hydroquinone $1: 10^{5}$, pyrocathechin $1: 10^{3}$, quinine sulfate $1: 6 \times 10^{3}$, thymol $1: 10^{3}$, cadmium salicylate $1: 10^{5}$, strontium salicylate $1: 10^{8}$. Hydroquinone is known in rosaceous plants (43), as in many others, but the relative amounts in different species do not seem to have been studied in detail.

Various materials of some interest in this connection have been used from time to time, either as drenches on blight cankers in pear orchards or as sprays on inoculated seedling trees. Lithium, methyl, and sodium salicylates when applied to the surfaces of active cankers in different solvents, consisting principally of alcohol and glycerine, had a definitely depressing effect on the progress of infection during periods of high temperatures. No such effect was clearly apparent in similar but small-scale tests with hydroquinone, pyrocatechin, and tannic acid, although there was some suggestion of it with the first of these.

Solutions in water of sodium salicylate ( 0.2 and 1.0 per cent), hydroquinone ( 1.0 per cent with 4.6 per cent glycerine), and glycerine ( 5 per cent) were each sprayed on several hundred seedling pear trees 4 days after these had been inoculated. Twenty days after inoculation, the average length of the blighted part in inches for 100 trees for each treatment in 6 consecutive rows was : control, 6.3 ; sodium salicylate 1 per cent, 5.3 ; sodium salicylate 0.2 per cent, 5.4 ; hydroquinone plus glycerine, 4.4 ; glycerine, 5.8 ; control, 6.8 .

The question is sometimes raised as to whether a coating of bordeaux mixture or other spray material has any effect on the resistance of the sprayed plant. In two experiments of 12 and 24 paired plants of Pyracantha angustifolia, half were sprayed with bordeaux mixture 1-1-50 in the greenhouse and all were inoculated at the tips when new growth had appeared above the sprayed parts (about 3 weeks after spraying). In one of these experiments the plants were cut back and inoculated a second time 9 weeks after spraying. In all three inoculations the blight was slightly greater on unsprayed plants but not significantly so.

A similar test was made later on 46 paired plants of Cotoneaster pannosa. Again the blight was somewhat more active in unsprayed plants, 
but the difference was even less than in the preceding tests, the average length of blighted part being 2.44 inches for sprayed plants and 2.63 for the controls.

Probably, with trees in the orchard, the difference in susceptibility due to spraying is slight if measurable at all.

\section{INHERENT RESISTANCE}

As far as is known, all the plants outside the rose family and many within it possess either a natural immunity to or a capacity to escape fire-blight infection. Even though all the genera in the subfamily Pomoideae (42) and some genera in all the other subfamilies contain susceptible plants, there are species or individuals in most of the genera, including Pyrus, which are highly resistant or immune. Resistance in the pear species and varieties has been of interest to many workers and has been studied extensively by Reimer (34).

Since many resistant root or intermediate stocks are now in use in pear orchards, the question sometimes arises as to whether these affect the susceptibility of the top varieties grown on them. The extensive planting of the highly resistant Old Home variety as an intermediate stock, usually on susceptible seedling roots, has provided abundant material for observation on this point. There is no evidence, however, of any change in the susceptibility of the top variety or of the roots, even, in the latter case, when the Old Home top is allowed to grow. Likewise when Cotoneaster Franchetii top (nearly immune) was grown on seedling pear stem and root in pots, the inherent susceptibility of the pear appeared to be unchanged up to more than one year from the time of grafting.

Seedlings of Pyrus communis vary widely in susceptibility to blight as in many other characters. This is illustrated by an experiment in which 500 seedlings from an Old Home $\times$ Farmingdale cross were planted at San Jose beside a like number of seedlings from trees of Winter Nelis and Beurre Hardy which had been exposed to Bartlett pollen. The varieties Old Home and Farmingdale are both highly resistant (34) although generally considered to be entirely of $P$. communis origin. Winter Nelis is among the more resistant of the commonly cultivated varieties, whereas Beurre Hardy is distinctly more susceptible, at least as to the extent of infections once established. The above seedlings were inoculated at the tips in April of the same year in which they were planted, with the results, as recorded 2 weeks later, shown in table 3 . Although a few of the Old Home $\times$ Farmingdale seedlings were later killed entirely by blight, the difference in resistance between this lot and the other two 
appeared to be greater after subsequent inoculations than is indicated by the table.

Something over 10,000 seedlings of Beurre Hardy and about 35,000 seedlings of Winter Nelis similar to those mentioned above have been grown for six years at San Jose with several inoculations each season. More than 5,000 of these have survived. It is not possible to state what part of this survival is due to inherent resistance and what part to crowding, dry weather, and other factors unfavorable to infection. However, the fact that a considerable number of the most vigorous trees in the planting have failed to develop appreciable if any infection suggests

TABLE 3

Susceptibility of Pear Seedlings of Different Parentage

\begin{tabular}{|c|c|c|c|c|}
\hline \multirow{2}{*}{ Source of seed } & \multicolumn{2}{|c|}{ Proportion infected } & \multicolumn{2}{|c|}{ Length of blighted part } \\
\hline & $\begin{array}{c}\text { Number trees } \\
\text { examined }\end{array}$ & $\begin{array}{l}\text { Per cent } \\
\text { blighted }\end{array}$ & $\begin{array}{c}\text { Number } \\
\text { examined }\end{array}$ & $\begin{array}{l}\text { Average } \\
\text { length }\end{array}$ \\
\hline Old Home $\times$ Farmingdale. & 490 & 16.5 & 100 & $\begin{array}{c}\text { inches } \\
1.79\end{array}$ \\
\hline Winter Nelis.............. & 481 & 46.9 & 200 & 2.32 \\
\hline Beurre Hardy . . .... . & 500 & 45.6 & 200 & 2.71 \\
\hline
\end{tabular}

that some of them are possessed of a high degree of inherent resistance. Reimer (35) has reported the occurrence of two highly resistant individuals out of 235 and 50 out of 704 in two lots of Pyrus communis seedlings.

The wide variability in any group of seedlings of pear or apple renders this material highly unsatisfactory for observations on the relation of inheritance to blight resistance. For this reason, tests were made with the progeny of a cross between Pyracantha angustifolia and $P$. Gibbsii var. yunnanensis. The former is highly susceptible to blight and remarkably uniform from seed. The latter is relatively resistant to blight, and while the seedlings vary appreciably, only an occasional plant is sharply different from its mates. The four plants which survived in the first generation from this cross were virtually identical in appearance and very similar to the seed parent $P$. angustifolia, in this respect resembling the recently reported behavior of pear hybrids (19). In resistance these were also very similar to each other but very near the pollen parent-directly opposed to the condition reported for pear (19).

Lots of seedlings were grown in pots to a suitable size for inoculation from three of the $\mathrm{F}_{1}$ individuals ${ }^{7}$. These lots are designated as hybrids

\footnotetext{
${ }^{7}$ Pollination of these was not controlled. It was assumed on the basis of behavior of the parents that cross pollination was not likely to occur.
} 
1,2 , and 3. At the time of inoculation, each lot was divided into four groups A, B, C, and D, including on one extreme (group A) the plants most resembling Pyracantha angustifolia in leaf characters and on the other (group D) those most like the other parent, with two intermediate groups between. Parallel with the inoculation of hybrid 2, inoculations were also made on shoots of the parent species (table 4). The results are

\section{TABLE 4}

Infection of $\mathrm{F}_{2}$ Seedlings of a Cross between Pyracantha Angustifolia and P. Gibbsit Yunnanensis Grouped in Relation to Resemblance to the Parents

\begin{tabular}{|c|c|c|c|c|}
\hline Plant & Group & $\begin{array}{c}\text { Number of } \\
\text { plants }\end{array}$ & $\begin{array}{l}\text { Number } \\
\text { blighted }\end{array}$ & $\begin{array}{c}\text { Length of } \\
\text { blighted part }\end{array}$ \\
\hline Hybrid $1 \ldots \ldots$. & $\left\{\begin{array}{l}\text { A } \\
\text { B } \\
\text { C } \\
\text { D }\end{array}\right.$ & $\begin{array}{l}20 \\
20 \\
20 \\
20\end{array}$ & $\begin{array}{r}7 \\
6 \\
12 \\
10\end{array}$ & $\begin{array}{c}\text { inches } \\
2.1 \\
2.5 \\
1.6 \\
2.4\end{array}$ \\
\hline Hybrid 2. & $\left\{\begin{array}{l}\text { A } \\
\text { B } \\
\text { C } \\
\text { D }\end{array}\right.$ & $\begin{array}{l}25 \\
25 \\
25 \\
25\end{array}$ & $\begin{array}{r}9 \\
7 \\
13 \\
11\end{array}$ & $\begin{array}{l}1.3 \\
0.8 \\
1.9 \\
1.8\end{array}$ \\
\hline Hybrid $3 \ldots$ & $\left\{\begin{array}{l}\text { A } \\
\text { B } \\
\text { C } \\
\text { D }\end{array}\right.$ & $\begin{array}{l}20 \\
20 \\
20 \\
20\end{array}$ & $\begin{array}{l}14 \\
11 \\
12 \\
14\end{array}$ & $\begin{array}{l}1.6 \\
1.8 \\
1.9 \\
1.7\end{array}$ \\
\hline $\begin{array}{l}\text { Pyracantha angustifolia.... } \\
\text { P. Gibbsii var. yunnanensis. }\end{array}$ & $\cdots \cdots$ & $\begin{array}{l}25 \\
25^{*}\end{array}$ & $\begin{array}{r}25 \\
0\end{array}$ & 3.7 \\
\hline
\end{tabular}

* Twenty-five shoots on 7 large potted plants. In all others, only one inoculation per plant was made.

fairly representative for $P$. angustifolia but are rather extreme for $P$. Gibbsii var. yunnanensis, which not infrequently blights for an inch or so at the tips of growing shoots after inoculation. As may be seen in the table, there is actually more blight in the $\mathrm{C}$ and $\mathrm{D}$ groups than in groups A and B. This seemed to be due to a somewhat lower state of vigor in the latter under the conditions of the tests; probably the differences are not otherwise significant. The results thus far suggest that resistance in this cross is at least partially dominant and, as in the pear (40), that resistance is not associated with any of the readily observable morphological characters. 


\section{DISCUSSION}

In the present state of our knowledge of disease resistance in plants, any discussion of this subject must come to rest on incomplete foundations. Nevertheless, since resistance is at the core of many problems in plant pathology, it may be worth while to consider those facts, even though fragmentary, that seem to bear some definite relation to this phenomenon. There is available, at any rate, sufficient evidence to indicate that resistance in plants is not due to a common cause but may be due, even in a single disease, to several distinct causes (11).

There is some evidence to support the concept that resistance to the initiation of fire-blight infection through wounds is due to factors different in some way from those which terminate the course of infection. For example, in certain of the experiments reported in this paper, the proportion of plants infected may be distinctly different in two groups, while the average extent of the infections is essentially the same. This view is further supported by the apparent capacity of the blight organism, once established in the plant, to alter markedly the physiological processes of the invaded tissues, evidenced among other ways by the early plasmolysis of cells (3) and by the "water-soaking" of the bark, presumably due to the release of water into the intercellular spaces.

That there is some relation between susceptibility and the nitrogen content of the tissues is indicated by the relatively greater susceptibility and apparently greater nitrogen content in young, actively growing parts than in older parts of the same plant, in etiolated shoots than in shoots exposed to light (23), in plants with ample water supply than in plants with low water (22), in the tissues immediately above the point of ringing than in those below the ring (13), and in plants with added nitrogen than in plants without such additions.

If nitrogen per se is a determining factor, it would seem to be in the form of some particular compound or group of compounds rather than as total nitrogen. In spring when growth is active and susceptibility high, the amino nitrogen in pear bark is relatively high as compared with the basic forms, whereas during the dormant season, the reverse is true (27). Furthermore, defoliation, which is followed by an increase in percentage of total nitrogen in apple shoots $(13,32)$, causes a reduction in susceptibility.

The vigorous growth of the pathogene in many and varied nonliving media, as well as in more than 125 species of rosaceous plants, suggests, however, that resistance is not due primarily to lack of nutrients in the plant but rather to the presence therein of some substance or substances 
in quality or concentration deterrent to the pathogene. In additional support of this view may be cited the failure of nutrients added with the inoculum to increase infection to any considerable degree in susceptible plants or to break down the high resistance or immunity in other closely related plants. The fact, noted by many workers, that the organism dies out rather quickly in blighted bark may also be considered as evidence bearing on this point.

Specific evidence has been presented (37) indicating that an arrested infection in the apple is usually held in check (prevented from revival) thereafter by the formation of a cicatrice at or near the margin of the infection. Such barriers are, however, relatively slow in formation and seem to appear only after the advance has been retarded or stopped by other means. The failure in this work to find evidence of suberin in wounded tissues until long after these have become closed to invasion by the blight organism suggests also that substances other than suberin are involved in preventing entrance through wounds. These, however, may be precursors of suberin or related compounds.

El-Sawy has shown ${ }^{8}$ that wounding causes increases in reducing substances of up to more than 50 per cent near the wounds in pear bark, and it is perhaps possible that these reach sufficient concentration to inhibit the organism under certain conditions. But quantitative determinations of these substances in the tissues immediately adjacent to wounds do not seem to have been made.

\section{SUMMARY}

Observations on the histology of the shoots of resistant and susceptible plants in general support those of earlier workers indicating that the size of intercellular spaces is a minor factor in determining the course of infection.

The tissues known to have a high nitrogen content are in general more susceptible than the nearest comparable tissues of lower nitrogen content.

The evidence suggests that the concentration of solutes in the nectar and perhaps also in the plant sap as affected by atmospheric humidity is of importance in the penetration of the organism into the plant and in the subsequent development of infection.

On the trunks of girdled pear and apple trees, the bark immediately above the point of girdling is more susceptible than that immediately below.

\footnotetext{
${ }^{8} \mathrm{El}-\mathrm{Sawy}, \mathrm{Abbas} \mathrm{H}$. Some effects of wounding on respiration and food reserves in the pear tree (Pyrus communis). Typewritten thesis, University of California.
} 
Slight wounds 2 to 4 inches below the points of inoculation of susceptible shoots did not cause any marked change in the development of infection.

Tests for gums and suberins failed to detect these substances at the margins of wounds until after the period during which the wounds would be susceptible to invasion.

Etiolation has a relatively slight influence on infection, while defoliation definitely reduced susceptibility.

In the progeny of a hybrid of Pyracantha angustifolia and P. Gibbsii var. yunnanensis, resistance seemed to be at least partially dominant. In the $\mathrm{F}_{2}$ generation there was no observed relation between susceptibility and resemblance to the parents. 


\section{LITERATURE CITED}

1. Anonymous.

1935. Pear blight control work in Lake County. Blue Anchor 12:2-4.

2. ARK, P. A.

1937. Variability in the fire-blight organism, Erwinia amylovora. Phytopathology $27: 1-28$.

3. Bachmann, Freda M.

1913. The migration of Bacillus amylovorus in the host tissues. Phytopathology $3: 3-13$.

4. BeEcher, H. W.

1844. The blight in the pear tree; its cause and a remedy for it. Magazine Hort. $10: 441-56$.

5. BeUTler, Ruth.

1929. Biologisehe Beobachtungen über die Zusammensetzung des Blutennektars. Sitzber. Gesell. Morph. und Physiol. in München 39:41-48.

6. BEutler, Ruth.

1930. Biologische-chemische Untersuchungen am Nektar von Immenblumen. Ztschr. Verglchn. Physiol. 12:72-176.

7. Brooks, A. N.

1926. Studies of the epidemiology and control of fireblight of apple. Phytopathology 16:665-96.

8. Cook, William S.

1923. The structure of some nectar glands of Iowa honey plants. Iowa Acad. Sci. Proc. 30:301-29.

9. ELMER, O. H.

1932. Growth inhibition of potato sprouts by the volatile products of apples. Science 75:193.

10. FreUNDLICH, HERBERT.

1932. Kapillarchemie Band II. 4th ed. Akademische Verlagsgesellschaft, Leipzig.

11. Goulden, C. H., K. W. Neatby, and J. N. Welsh.

1928. The inheritance of resistance to Puccinia graminis tritici in a cross between two varieties of Triticum vulgare. Phytopathology 18:631-58.

12. Haber, Julita Moesel.

1928. The relationship between Bacillus amylovorus and leaf tissues of the apple. Pennsylvania Agr. Exp. Sta. Bul. 228:1-15.

13. Harvey, E. M.

1923. A study of growth in summer shoots of the apple with special consideration of the rôle of earbohydrates and nitrogen. Oregon Agr. Exp. Sta. Bul. 200:1-51.

14. Heald, F. D.

1927. Leaf invasion by Bacillus amylovorus. Northwest Sci. 1:76-79.

15. Hildebrand, E. M.

1937. The blossom-blight phase of fire blight, and methods of control. New York (Cornell) Agr. Exp. Sta. Memoir 207:1-40. 
16. Hildebrand, E. M., and A. J. Heinicke.

1937. Incidence of fire blight in young apple trees in relation to orchard practices. New York (Cornell) Agr. Exp. Sta. Memoir 203:1-36.

17. Hildebrand, E. M., and L. H. MacDaniels.

1935. Modes of entry of Erwinia amylovora into the flowers of the principal pome fruits. [Abstract.] Phytopathology 25:20.

18. Hopkins, E. F.

1938. A new and rapid dehydration process for vegetables. Science 87:71-72.

19. Hsiong, S. L., and E. M. Hildebrand.

1937. Maternal inheritance in pears. Phytopathology 27:861-62.

20. Johnson, James.

1937. Relation of water-soaked tissues to infection by Bacterium angulatum and Bact. tabacum and other organisms. Jour. Agr. Research 55:599-618.

21. Krasnoseliskaja-Maximova, T. A., T. V. Kulagina, K. I. Orlova, S. N. FiliMONOVA, and N. V. CugReJEVA.

1937. [Apple tree physiology in relation to soil conditions.] (Translated title.) Compt. Rend. (Doklady) Acad. Sci. U.R.S.S. 16(9):469-72.

22. Kraus, E. J., and H. R. Kraybill.

1918. Vegetation and reproduction with special reference to the tomato. Oregon Agr. Exp. Sta. Bul. 149:1-90.

23. Kraybill, Henry R.

1923. Effect of shading and ringing upon the chemical composition of apple and peach trees. New Hampshire Agr. Exp. Sta. Tech. Bul. 23:1-27.

24. LinCOLN, F. B.

1926. Is phloridzin present in the pear tree? Amer. Soc. Hort. Sci. Proc. 23: 249-52.

25. Mallery, T. D.

1935. Changes in the osmotic value of the expressed sap of leaves and small twigs of Larrea tridentata as influenced by environmental conditions. Ecological Monographs 5:1-35.

26. Miller, P. W.

1929. Studies of fire blight of apple in Wisconsin. Jour. Agr. Research 39: 579-621.

27. Mulay, A. S.

1932. Seasonal changes in the composition of the non-protein nitrogen in the current year's shoots of Bartlett pear. Plant Physiol. 7:107-18.

28. Nightingale, Alice Allen.

1936. Some chemical constituents of apple associated with susceptibility to fireblight. New Jersey Agr. Exp. Sta. Bul. 613:1-22.

29. Nixon, E. L.

1927. The migration of Bacillus amylovorus in apple tissue and its effect on the host cells. Pennsylvania Agr. Exp. Sta. Tech. Bul. 212:1-16.

30. PARKeR, K. G.

1936. Fire blight: Overwintering, dissemination and control of the pathogene. New York (Cornell) Agr. Exp. Sta. Memoir 193:1-42. 
31. PierstorfF, A. L.

1931. Studies on the fire blight organism, Bacillus amylovorus. New York (Cornell) Agr. Exp. Sta. Memoir 136:1-53.

32. Proebsting, E. L.

1925. The relation of stored food to cambial activity in the apple. Hilgardia 1:81-106.

33. Rawlins, Thomas Ellsworth.

1933. Phytopathological and botanical research methods. ix $+156 \mathrm{p}$. John Wiley \& Sons, New York.

34. Reimer, F. C.

1925. Blight resistance in pears and characteristics of pear species and stocks. Oregon Agr. Exp. Sta. Bul. 214:1-99.

35. REIMER, F. C.

1927. Seventh Annual Placer County Fruit Growers' Convention, Auburn, California. October, 1927. p. 76-81.

36. Rosen, H. R.

1936. Mode of penetration and of progressive invasion of fire-blight bacteria into apple and pear blossoms. Arkansas Agr. Exp. Sta. Bul. 331:1-68.

37. SHAw, Luther.

1934. Studies on resistance of apple and other rosaceous plants to fire blight. Jour. Agr. Research 49:283-313.

38. SHAW, LUTHER.

1935. Intercellular humidity in relation to fire-blight susceptibility in apple and pear. New York (Cornell) Agr. Exp. Sta. Memoir 181:1-40.

39. STEWART, V. B.

1913. The fire blight disease in nursery stock. New York (Cornell) Agr. Exp. Sta. Bul. 329:313-72.

40. Thomas, H. EARL.

1927. Kieffer pear seedlings and fire blight resistance. Torrey Bot. Club. Bul. 54:583-5.

41. Thomas, H. Earl, and P. A. ARK.

1934. Nectar and rain in relation to the fire blight disease. Phytopathology 24:682-85.

42. Thomas, H. EarL, and P. A. ArK.

1934. Fire blight of pears and related plants. California Agr. Exp. Sta. Bul. $586: 1-43$.

43. WEHMER, C.

1931. Die Pflanzenstoffe. 2d ed. Gustav Fischer, Jena.

44. White, Philip R.

1938. "Root pressure"-an unappreciated force in sap movement. Amer. Jour. Bot. 25:223-27. 